\title{
TYPES OF POLYPHONY IN DESIGNING THE COREOGRAPHY OF MIRSKA PJENIJA BY SRDJAN JAĆIMOVIĆ
}

\author{
UDC 781.42 Mirska pjenija
}

\section{Danijela Stojanović, Bojana Milošević}

University of Niš, Faculty of Arts in Niš, Republic of Serbia MA Music Theory and Pedagogy, Niš, Republic of Serbia

\begin{abstract}
Polyphony, as a composing technique, has the same function in every historically artistic period - the development and enrichment of melodic lines. What distinguishes polyphony treatment throughout the epochs is the different sound impression of the stylistic musical period in which the composition was created. Musical language of choreographed scenes in Mirska pjenija by the composer Srdjan Jacimović is to a large extent the musical language of our epoch, a language of postmodern orientation. The piece abounds with the impressionistic presentation of the atmosphere through musical expressing of the text. A detailed polyphonic analysis of the composition indicates the use of different types of polyphony in each of the choreographed scenes individually, which are systematically separated and explained in this paper.
\end{abstract}

Key words: polyphony, types of polyphony, choreographed scenes, Mirska pjenija, Srdjan Jaćimović.

\section{INTRODUCTION - WHAT IS `POLYPHONY`?}

The pieces composed by polyphonic technique dominated European music from the XII to mid XVIII century. Polyphony is a compositional technique based on the parallel development of several equal melodies, in which the melodic (linear, horizontal) principle prevails. The term itself is treated in two ways - in a narrower and broader sense. In the broader sense, polyphony is based on a tonal harmonic system, with melodic lines shaped according to the requirements of contrapuntal technique. Polyphony, in a narrow sense, denotes a multi-voiced movement in which none of the sections dominate, regardless of the natural prominence of external voices din a multi-voiced movement, but there is a balance of voices, where the vertical logic of matching voices does not have to

Received July 2019 / October 2019

Corresponding author: Danijela Stojanović

University of Niš, Faculty of Arts in Niš

E-mail: danijela63@yahoo.com 
comply with the laws of the baroque-classical science of harmony based on a tonal system (Перичић, 1991).

Polyphony in the narrower and broader sense is characteristic for the late Middle Ages, Renaissance and Baroque, while in classicism and romanticism, as well as in contemporary music, the synthesis of its structural principles with the principles of homophony formation is done (Peričić, 1987; DeVoto, 2007; Мюллер and Григорьев, 1977; Merriam-Webster Dictionary).

\subsection{Types of Polyphony}

There are two main types of polyphony in a composer's work: imitative and nonimitative polyphony.

\subsubsection{Imitative polyphony}

Imitation provides the unity of voices of a musical piece, regardless of their mutual contrast and expressed uniqueness (Божанић, 2012). "Repeat 'word by word' or 'note by note' would not be quite appropriate, because there is nothing in nature absolutely the same. Consequently, imitation implies repetition with a different degree of similarity. Repeating, not quite right, but so that the principle of repetition is still obvious, the composer respects in nature the necessary law of unity and diversity" (Кирнарская, 1997, 51).

Apart from the basic division in strict and free, other types of imitation are represented:

- imitation in augmentation,

- imitation in diminution,

- imitation in inversion,

- retrograde imitation,

- retrograde inversion,

- canonical imitation ${ }^{1}$,

- stretto.

\subsubsection{Non-imitative polyphony}

The non-imitative or contrastive polyphony represents a type of polyphony in which different, often contrasting melody lines are combined. What is characteristic of this type of polyphony is the individualization of voices, which is most often realized through the direction of the movement of the melody line, the register, the rhythmic patterns, and the structure of the interval. The contrast of melodic voices can be expressed using these techniques, but also with other means including dynamics domains, national specifics, etc. In the polyphony of contrast, various polyphonic techniques are widely used, particularly a complex counterpoint in its numerous modifications (Осипова, 2006).

Here are the following types of non-imitative polyphony:

- harmonic polyphony - the type of fracture located on the borderline between polyphony and homophony: the primary concept is homophonous, but the sections of all voices are melodically emphasized; the leading role of the main melody line

\footnotetext{
${ }^{1}$ For some authors, canonical imitation and stretto are synonymous. When it comes to canonical imitation, the imitating section as a whole brings a melodic line to the theme; canon is an independent movement of polyphonic vocal or instrumental music based on the principles of strict imitation, while canonical imitation is part of some form. Stretto is a type of imitation introduced by Baroque masters, in which the appearance of the answer begins before the topic is completed; the topic must be composed in such a way that it is suitable for imitation in stretto.
} 
is obvious, and in the accompanying voices there are generally no specifically contrapuntal acts such as imitation, convertible counterpoint and the like (Перичић, 1987; Salop, 1964),

- sub-voiced polyphony - a phenomenon that belongs primarily to the folk tradition of mainly East Slavic origin (Russian, Belarussian, Ukrainian); polyphony is formed by the simultaneous combination of different versions of the same melody that are absolutely identical, and practically each of them can claim to be the main melody (Всеволодович, 1990; Шлемович, 2001),

- duet polyphony - a type of polyphony when two distinct melodic lines stand out from the homophonic harmonic base, which are in counterpoint to each other, more or less, and elements of imitation are also observed (Перичић, 1987),

- a series of non-imitative techniques and procedures:

- adding contrapuntal lines of new to the already exposed ones,

- adding contrapuntal lines based on already known motif material-contrapuntal fusion of thematic elements that have previously been specifically exposed,

- ostinato - in most cases it has no contrapuntal sense at all, but is a supporting figure of harmonic significance; rarer are examples where the ostinato is more independent, and one could speak of a certain counterpoint to the leading melody (Перичић, 1987).

\subsection{Polyphony in Serbian artistic music of the XXth century}

In the professional opus of the XXth century composers, polyphony and polyphonic procedures are evident and found in a large number of their works, throughout different musical styles. The XXth century period is the most dynamic period in the history of human civilization due to the development of science and technology, the emergence of new media (film, radio gramophone) through the rapid development of cities with a large population, and the phenomenon of mass culture (jazz, cabaret, circus). The second half of the XXth century brought many directions and methods, a constant tendency towards new and experimental approaches. In that period, there were prominent composers like Josif Marinković, Stevan Stojanović Mokranjac (both nurtured Serbian romanticism), who showed great knowledge of polyphonic technique in their spiritual pieces. The most important figures of musical life between the two world wars - Petar Konjović, Miloje Milojević and Stevan Hristić - also cultivated the polyphony technique in their spiritual pieces, where Hristić is especially distinguished for his excellent writing of polyphonic texture (Веселиновић-Хофман, 2007).

The first generation of our composers, who fully accepted modern expressive means, the so-called "Prague group", has been operating in Belgrade since 1927. The one who stands out from that group, according to the use of polyphony, is Milan Ristić. In his opus, polyphony plays a major role in structuring of the piece. Neoclassicism is basically the starting point for the generation of composers born in the late 30s, 40s and 50s. In the middle of the century, neoclassicism with elements of Baroque orientation - neobaroque was born. It was highly different from the formal categories of baroque (fugue, passacaglia, oratorio, passion), and the use of compositional techniques of baroque (polyphonic technique, frontal development of thematic material, motor). The most important composers who have created in the neobaroque are Nikola Hercigonja, Enriko Josif and Dragutin Čolić (Веселиновић-Хофман, 2007).

The second wave of Serbian music avant-garde began in the first years of the seventh decade of the XXth century. Representatives of this trend are the composers born in the 
fourth decade of the XXth century: Petar Bergamo, Petar Ozgijan, Vladan Radovanović, Rajko Maksimović. These composers emphasized the tendency for authentic solutions to their artistic expression as part of the exploration of a new-integral serialism, music of sound colors, micropolyphony, aleatorics of the Polish school. Thus, it is encountered in Ozgijan the polyphonization of the structure, in Radovanovic the micropolyphonic structure, and in Popović, both the polyphonic structure and the polyphony of the musical texture (Веселиновић-Хофман, 2007).

\section{SRDJAN JAĆIMOVIĆ - THE COMPOSER}

Srdjan Jaćimović (1960-2006) was a Serbian composer, professor and producer. Jaćimović was one of the more productive and influential figures of his time in the field of music. He spent his working period in the field of harmony and polyphony. In the 1980s, he was a member of, "The Magnificent Seven" (,Sedam veličanstvenih”), who had the role of "promoting" artistic music through the organization of concerts (Kolarac Endowment) and other activities. He left behind a compositional opus consisting of twenty-seven pieces of vocal, vocal-instrumental and instrumental music, teaching textbooks, theoretical works, theater and film music. Among other things, he composed: Trahinians (Trahinjanke), cantata by Sofokle for soloists, great orchestra and choir, Akathist Hymn to Jesus Christe`s Apostle Andrew (Akatist apostolu Isusa Hrista Andreju prvozvanom) - for soloists and mixed choir, according to the text of Arsenije Milošević, Madrigal of Disgrace (Madrigal de la Honte), for mixed choir, Six songs from the North (Šest pesama sa severa) by Miloš Crnjanski, for soprano and a string quartet etc. He also wrote theater music, music for the film A White Suit (Belo odelo), as well as essays and textbooks in the field of musical theory.

His strength, power, emotions and perfection came from every written tact, motif, phrase. In his pieces, composer Srdjan Jaćimović strived to merge "the old" and "the traditional" (usually expressed in voices through vocal melody), and "the modern" expressed through harmony, choice and treatment of instruments, but also through frequent interweaving of vocal and instrumental sections. This can also be observed in the composition Mirska pjenija, in which the synthesis of elements of medieval music and the effects of the music of impressionism creates a set of spirit of ancient and modern expression.

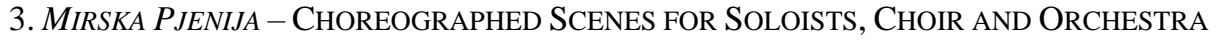

The composition Mirska pjenija, to which the composer added the descriptive title Choreographed Scenes - was written for soloists (soprano and tenor), a big orchestra and mixed choir. Composer Srdjan Jaćimović was a great admirer of Igor Stravinsky`s opus and work. On the basis of this, it can be assumed that the idea and inspiration of the very term of 'choreographed scenes` undoubtedly came from the composition The Wedding (Свадебка) by Igor Stravinsky - Russian choreographic scene with four solo voices, mixed choir, four pianos and percussion ensemble.

Mirska pjenija is a piece dedicated to the tradition of the Serbian people and abounds in "impressionistic" depicting the atmosphere, because the composer uses instruments for the purposes of coloring. The voice treatment is diverse, starting with a recitative of the solo tenor section, which represents an association to the priest's recitative, as well as in the excerpts of the older folk tradition (in choral sections, above all) to the "modern" treatment of voice as an "instrument". The frequent changes in tempo and meter by the composer reveal the burning past of the Serbian people. 
The piece is composed by using texts of folk and artistic poetry from Kosovo and about Kosovo. The excerpts were chosen so that the whole tradition of the Serbian people was reflected in them, important moments from spiritual and everyday life (celebration of the Saint, courting of youth, wedding and marriage, family relations, sadness for the deceased, etc.), as well as the historical event that had left the deepest trace on the Serbian soul - the Battle of Kosovo. The text from folk poetry consists of epic and lyrical poems from the Kosovo cycle, whose fragments had been taken from an anthology Folk Literature of Serbs in Kosovo and Metohija (Народна къижевност Срба на Косову и Метохији), edited by Vladimir Bovan. The artistic text consists of three parts: the first part is The Prayer to the Lord Asleep (Molitva zaspalom Gospodu), by Arsenije Carnojević, the second part are the fragments from the collection Persecution of the Serbs: Kosovo in $20^{\text {th }}$ Century Poetry (Изгон Србаља: Косово у песништву двадесетог века), edited by Raša Perić, and the third is taken from the epistle Miroslav's Gospel (Miroslavljevo jevanđelje).

The texts of the poems and their harmony are closely linked, stemming from the desire to deepen the interpretation of the text through music. In some parts, chorus sections take on the role of instruments, in which the composer has equally treated the voices and instruments in a certain way.

Formally speaking, the composition Mirska pjenija is the most similar to oratorio, composed of several sections, caused by different texts. The form of the composition is rhapsodic, recomposed.

Table 1 Macroform of composition Mirska pjenija

\begin{tabular}{|c|c|c|c|c|}
\hline $\begin{array}{l}\text { Main parts } \\
\text { (choreographed } \\
\text { scenes) }\end{array}$ & $\begin{array}{c}\text { Introductory + part I } \\
\text { (First scenes) }\end{array}$ & $\begin{array}{c}\text { Part II } \\
\text { (Second scenes) }\end{array}$ & $\begin{array}{c}\text { Part III } \\
\text { (Third scenes) }\end{array}$ & $\begin{array}{c}\text { Part IV } \\
\text { (Fourth scenes) }\end{array}$ \\
\hline Duration & mm. 1-119 & mm. 120-200 & mm. 201-372 & mm. 372-524 \\
\hline Form & $\begin{array}{c}\text { Introduction }+ \\
\mathrm{a}+\mathrm{b}+\mathrm{a} 1+\mathrm{c}\end{array}$ & $a+b+c$ & $\mathrm{a}+\mathrm{b}+\mathrm{b}_{1}+$ bridge & $a+b+c+$ Coda \\
\hline Harmonical base & $\begin{array}{l}\text { F-minor } \\
\text { F-Dorian } \\
\text { B-major } \\
\text { A-Mixolydian } \\
\text { D-Mixolydian } \\
\text { B-major } \\
\text { F-sharp minor }\end{array}$ & $\begin{array}{l}\text { F-sharp Phrygian } \\
\text { F-sharp Dorian } \\
\text { F-sharp Phrygian } \\
\text { B-minor }\end{array}$ & $\begin{array}{l}\text { B-major } \\
\text { A-Mixolydian } \\
\text { B-major } \\
\text { A-Mixolydian } \\
\text { H-major } \\
\text { D-major } \\
\text { F-minor } \\
\text { D-major }\end{array}$ & $\begin{array}{l}\text { F-sharp Phrygian } \\
\text { B-minor } \\
\text { B-major }\end{array}$ \\
\hline
\end{tabular}

Table 1 shows the main parts of the composition, each part representing one choreographed scenes each of which is divided into a smaller or larger number of subsections. The first scenes consists of five subsections (Introduction $+a+b+a 1+c)$, Second consisting of three $(a+b+c)$, Third consisting of four $(a+b+b 1+$ bridge $)$ and final Fourth scenes - is also with four sections $(\mathrm{a}+\mathrm{b}+\mathrm{c}+$ Coda).

On the other hand, the harmonic means by which the composition was created and designed - the use of clusters, altered tones and chords, a pale tonal impression, fall within the range and achievements of impressionism, while the luxurious use of old-church scales brings the tonal plan in connection with the music of the Middle Ages, thus creating a sound impression of archaic. 


\section{TyPes of PolyphONy in CHOREOGRAPHEd SCENES OF MIRSKA PJENIJA}

The process of analyzing polyphony types of choreographed scenes of Mirska pjenija by composer Srdjan Jaćimović is based on a polyphonic analysis of this selected piece. It is necessary to examine all the elements of polyphony and to extract the basic music materials - theme or the leading melodic line, in order for the analysis process to be based on the correct differentiation of the musical materials.

The composition Mirska pjenija does not contain formal polyphonic patterns, but polyphony takes place during the score and requires a careful analysis of the voices or sections in which it most often appears.

By analyzing the composition in detail, specifically considering the treatment of polyphony, one finds the fact of the most common aspect:

- as a free imitation of the leitmotif in the wind section,

- a strict imitation in the sections of male and female choir voices,

- imitative technique in inversion, in chorus and bassoon sections (a short melodicrhythmic motif is imitated),

- imitation in a strict inversion,

- a short melody-rhythmic pattern in the flute section that is imitated in the clarinet section

- a free imitation of the chord-harmonic structure on the tonic seventh chord.

The text that follows shows one type of polyphony from each choreographed scenes. The examples are chosen so that each represents a different type of polyphony from the previous and the following examples.

\subsection{A leitmotif in the composition Mirska pjenija}

According to some authors (Kolenc, 2015; Whittall, 2019), the leitmotif, in its very sense, means a theme or other coherent musical idea, clearly defined to retain its identity if it is modified in later phenomena. Its purpose is to represent or symbolize a person, object, place, idea, state of mind, supernatural power, or any other ingredient in a dramatic work. When running a leitmotif, the object to which it is connected is in some way revoked. The leitmotif can be musically unchanged during its repetition, or changed in rhythm, interval structure, harmony, orchestration or accompanying, but can also be combined with other leitmotifs (Example 1).

Example 1 A leitmotif in a bassoon section in the composition Mirska pjenija (mm. 2-5)

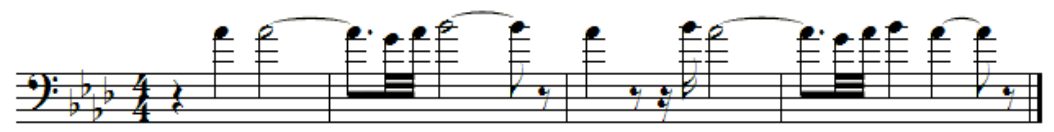

The structure of the melody line of the leitmotif of the composition Mirska pjenija (bassoon, mm. 2-5), belongs to the substructure of the monophony within the monophony, which is the earliest and simplest form of single-voiced thematic in polyphony ('axis' and 'core'). According to Skrebkova Filatova (1996) "the axis can permeate the whole melody, but it can also be made complex by the adjacent tones that play and 'envelop' the baseline" (Скребкова Филатова, 1996). The melody can be divided into two layers: the first and the basic layer-tone at A-flat, which forms the base, the backbone of the melody, and the second layer - a group of repeating tones around the A-flat, which make the melody more delicate. 
Since there is no written data (or accompanying program) about the character of the leitmotif of this composition, it cannot be convincingly claimed what it symbolizes. However, based on the entire sound scenes, and more importantly, on the basis of the text, it can be assumed that the leitmotif symbolizes the suffering and troubles of the Serbian people in migrations and wars throughout its history.

The leitmotif is then imitated in the section of the horn at prima (mm. 9-11), and belongs to the type of free imitation of the theme because it contains certain rhythmic and melodic changes (Example 2).

Example 2 Imitative polyphony of the leitmotif in the horn section, Introductory part (mm. 9-11)

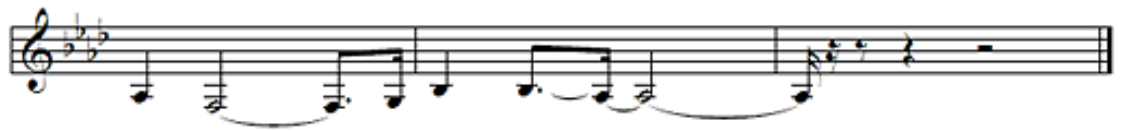

Symbolically, the composition begins with the exposure of a leitmotif - a view of how everything arises and evolves from it, gradually, with the skill of gradation, it evolves and completes the entire composition. The leitmotif, which is the main carrier of the idea of the entire composition and also the main constructive element, is exhibited in different sections and various registers. The leitmotif is exhibited for the first time in the sections of bassoon (mm. 2-5) and horn (mm. 9-11) by the free imitation technique in the sections of the string ensemble and the choir with lyrics taken from the poem Prayer to the Lord Asleep (Molitva zaspalom Gospodu) by Arsenije Carnojević (mm. 84-90). The third occurrence of the leitmotif was assigned to the trumpet section (mm. 114-117), in subsection $c$ of the First scenes. Its development leads to an extremely strong climax during the last interpretation (subsection $b$ of Part III, mm. 305-325). The latest appearance of the leitmotif is announced by the sections of the flute, the piano ( $\mathrm{mm}$. 288-301), the clarinet and the second violin, interpreting its rhythmic-melodic idea (mm. 302-304). Modulating in F-minor, with which begins the composition and the first presentation of the leitmotif, skillfully prepared and announced. The leitmotif is last exhibited in the sections of the oboe and the chorus (alt and tenor) (mm. 306-311). The leitmotif is then imitated in the tenor and trombone section (mm. 313-316) and belongs to the type of free imitation of the theme. There is also significant working with the leitmotif that has been achieved through a seven-tone external extension of the monophonic movement of the melody line (except for the bass playing a pedal tonic role) (mm. 316-322). The horn section doubles the listed sections varied. The choir brings a text from Miroslav's Gospel (Miroslavljevo jevanđelje), Serbian largest Cyrillic monument: Посушаствова во ипи где глагоље: What is a man. Life is the letter of God, and indeed it is the sharpener of the sword, to which the recitative (mm. 323-325) is related to the text the Lord. The development of the leitmotif was achieved by the gradual complexing of the sections involved in its performance and also the inclusion of choral voices that bring ideas and thoughts through verses, thus increasing the dramatization of the action (first presentation-bassoon and horn, second presentation-strings and choir, third presentation-trumpet, fourth-flute, piano, clarinet, second violin, oboe, choir).

\subsection{Polyphony in the First Choreographed Scenes}

The First scenes (mm. 1-119) is characterized by a composer's illustration of the foggy morning and the suffering of the Serbian people. The text accompanying music are the 
verses taken from the poem Prayer to the Lord Asleep (Molitva zaspalom Gospodu) by the Patriarch Arsenije III Ćarnojević. The verses from the XVII century, which skillfully follow every tone and motif of this scenes, show how much suffering of Patriarch Čarnojević and sense of responsibility for the Serbian people should have been, at the time in which he wrote those verses. Polyphony is shown in the First scenes in the following ways:

- Introductory part - in the form of imitative polyphony, free imitation of the leitmotif in the wind section (first thematic material, mm.2-11);

- Subsection $a$-in the form of strict imitation, on an interval of octaves, in sections of male and female choir voices (second thematic material, m. 18);

- Subsection $b$ - by a procedure of adding a melody line of new content in the bass section, which counterpoints already exposed subject themes in soprano and aria sections (third thematic material, m. 62);

- Subsection $a_{1}$ - by imitation inversion technique in chorus and bassoon sections a short one-tact melodic-rhythmic motif was imitated (fourth thematic material, $\mathrm{m}$. 77) (Table 2).

Table 2 Types of Polyphony in the First scenes

First scenes (mm. 1-119)

Introductory part: imitative polyphony - free imitation

Subsection $a$ : imitative polyphony - strict imitation

Subsection $b$ : a procedure of adding a melody line of new content

Subsection $a_{l}$ : imitative polyphony - imitation in inversion

Subsection $c: /$

The rhythmic-melodic motif of the recitative (First scenes, Subsection $a_{1}$, mm. 77), made of four sixteenths, is simultaneously exposed by the imitation technique in inversion in the chorus sections, and later - in the bassoon section ( $\mathrm{mm} .82)$ : by the melody lines of the chorus and the bassoon, the direction of the interval is changed, the ascending intervals of the recitative become in the imitations descending ones, and vice versa (Example 3 ).

Example 3 Imitation in inversion in the sections of the recitative and the bassoon (fourth thematic material, Subsection $a$ of First scenes)

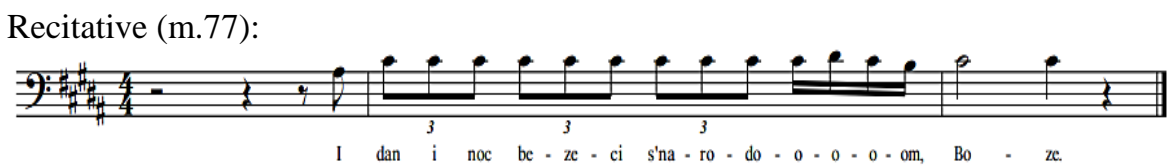

Bassoon (m.82):

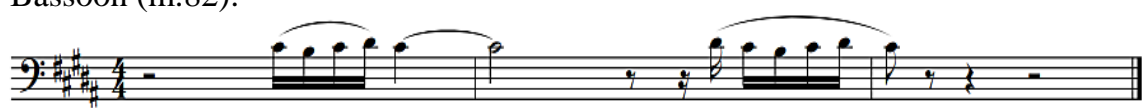

\subsection{Polyphony in the Second Choreographic Scenes}

The Second scenes of the composition Mirska pjenija (mm. 120-200) is the shortest in duration and with a modest tonal plan. Frequent contrasts are striking, and the section 
contains two parts that, in a completely homophonic structure, alternate, i.e. they change - the tutti section and the recitative (calm and combat sections).

In this part of the composition, a little less use of the law of polyphony and polyphonic work can be found. Polyphony in this part of the composition is applied in two ways:

- Subsection $a$ - the type of duet polyphony that takes place in the sections of the soprano (which section is doubled by the section of the oboe) and the aria. It is an imitation of a one-tact melodic-rhythmic motif of dotted rhythm (fifth thematic material, m. 140);

- Subsection $c$ - imitation in strict type of inversion, a short melodic-rhythmic pattern, shown in sixteenth sextolets in the flute section, is imitated in the clarinet section (sixth thematic material, m. 195) (Table 3).

Table 3 Types of Polyphony in the Second scenes

\begin{tabular}{l}
\hline \multicolumn{1}{c}{ Second Scenes (mm. 120-200) } \\
Subsection $a$ : duet polyphony \\
Subsection $b$ : / \\
Subsection $c$ : imitative polyphony - imitation in strict type inversion \\
\hline
\end{tabular}

In subsection $a$ of the Second scenes (mm. 120-153) the type of duet polyphony is observed in the sections of the arias and soprano (with the doubled melody line in the section of oboe) that are singled out in a mostly homophonic structure (mm. 140-143). The melody of the aria, the short one-tact content of the dotted rhythmic pattern is imitated in the section of the soprano and is considered a duet type polyphony (Example 4).

Example 4 Duet polyphony in sections of arias and soprano, fifth thematic material, subsection $a$ of Second scenes (mm.140-143)

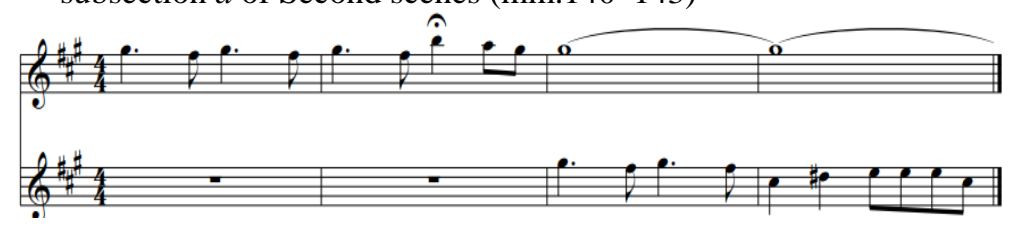

\subsection{Polyphony in Third Choreographed Scenes}

The Third scenes (mm. 201-371), the richest tonally, is characterized by an often intertwining of the motifs shown in the previous parts, as well as rigorousness of the section. Repeating the same melodic patterns with different texts is evident. The main poetic thought of the text is given by the choir, symbolically as the voice of the people, and the text is combined from Miroslav's Gospel (Miroslavljevo jevanđelje), the most important Cyrillic monument of Serbian, or Serbian-Slavic literature from the XII century, and from fragments of folk literature of Serbs in Kosovo and Metohija.

The use of polyphony is in this part realized in choral sections and aria section on two occasions:

- In subsection $a$ - by the procedure of adding contrapuntal lines of new content. It is the technique of the cantus firmus, where the already known melody is located in the section of the soprano, while a new thematic material counterpoints in the alto (seventh thematic material, m. 237). 
- In subsection $b_{1}$ - the melody lines of the new content are in the sections of the soprano and the aria, parallel to the already seen material in the sections of the alto and the tenor (eighth thematic material, m. 326) (Table 4).

Table 4 Types of Polyphony in the Third scenes

Third scenes (mm. 201-371)
Subsection $a$ : a procedure of adding contrapuntal lines of new content
Subsection $b:$ /
Subsection $b_{1}$ : a procedure of adding contrapuntal lines of new content
bridge: /

In subsection blof the Third scenes in the section of the soprano (mm. 326-360), a new thematic material is exhibited simultaneously with the thematic material that was previously represented in the melody lines of the alto and the tenor (mm. 280-299, subsection $b$ of the Third scenes. The soprano section is doubled by the section of the solo soprano. The text that brings the sections of the chorus is: Out of sadness I made my face ugly for my beloved, I cut my hair for my brother-in-law. The hair will grow, the face will heal. I extracted my eyes for my brother, out of sadness (3a dpazог лице нагрдила ја, за девера прстенског одреазала косе, тужна сам. Косе ће порасти, лице ће зарасти. За брата рођеног, тужна сам очи вадила) (Example 5).

Example 5 A procedure of adding contrapuntal lines of a new content to the already exposed ones, eighth thematic material, subsection $b_{1}$ of Third scenes(mm.326-360)

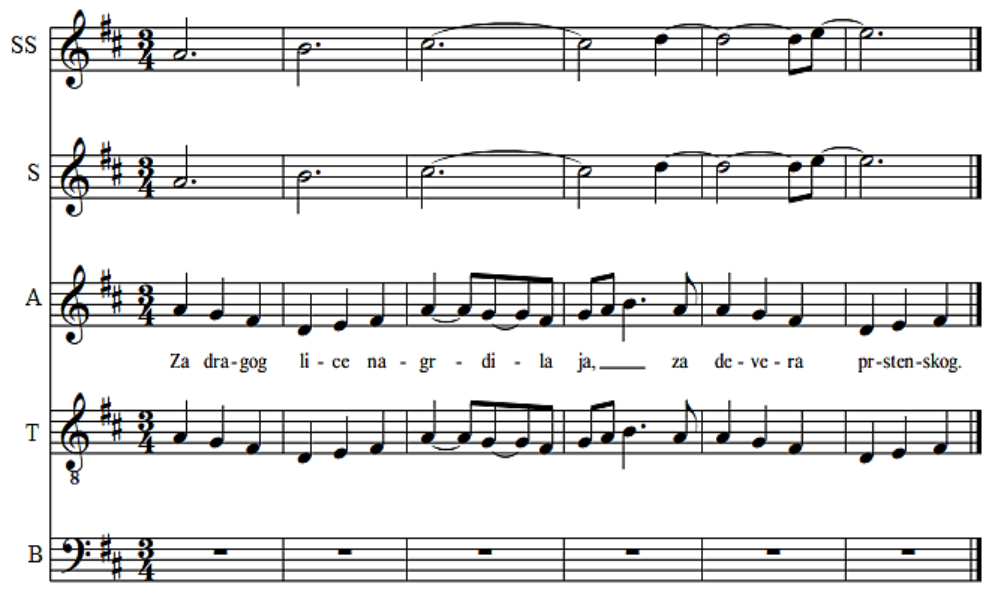

\subsection{Polyphony in the Fourth Choreographed Scenes}

From the harmonic aspect, the last, Fourth scenes (mm. 372-524), is "the most dissonant" scenes, without a stable tonal base and with the greatest use of clusters and altered tones. Along with the harmonic plan, the action is described by interwoven texts of various themes taken from folk songs in the choir and aria sections. One of the many examples of the typical impressionistic expressing the atmosphere in this part is the tragic text of the drowned girl 
Kalena drowned (Kalena se utopila), where the larger waves are symbolically imitated by external chorus voices, while the smaller waves are imitated by inner voices.

The polyphony in the final Fourth scenes of the composition is shown in the following types:

- In subsection $b$ - the procedure of joining contrasting themes, by merging thematic materials previously exposed separately, in sections of the chorus; (thematic materials are especially exposed in Fourth scenes, Subsection $b$ (m. 412) and Third scenes, Subsection $a$ (m. 237).

- In subsection c-imitative polyphony, where the thematic material brought by the sections of the choir is imitated in unison in the sections of oboe, trumpet and solo soprano (ninth thematic material, m. 459);

- In Coda - the imitative polyphony is at interval of sixth, and is free by type (tenth thematic material, m. 513) (Table 5).

Table 5 Types of Polyphony in the Fourth scenes

\begin{tabular}{l}
\hline \multicolumn{1}{c}{ Fourth scenes (mm. 372-524) } \\
\hline Subsection $a$ : / \\
Subsection $b$ : the process of joining contrasting themes \\
Subsection $c$ : imitative polyphony - strict imitation \\
Coda: imitative polyphony - free imitation
\end{tabular}

In subsection $b$ of Part IV (mm. 400-453), there is thematic material previously presented in the alto (mm. 412) is exhibited in the bass section (mm. 442). Parallel with the bass, the thematic material presented in the sections of the tenor and the alto, is very similar to the material of their sections from Part III subsection $a$ (mm. 237-246) Angrily curses Drenovka girl ...(Ljutokune Drenovka devojka...), this time with the text All the fish - sisters-in-law ...(Sveribice - jetrvice...). It is about the same rhythmicmelodic pattern, modified in the form of minor interval changes, but which retained its character in any case (Example 6).

Example 6 The process of joining contrasting themes previously exposed separately, subsection $b$ of Fourth scenes (mm. 442-445)

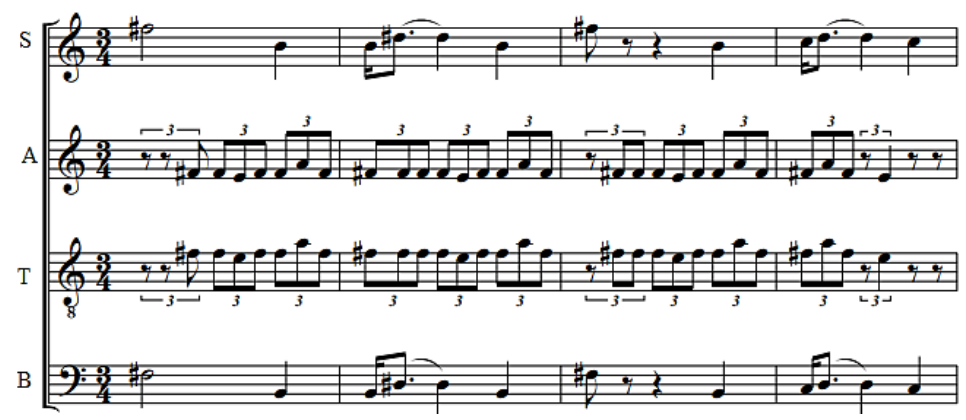




\section{CONCLUSION}

The analysis of choreographed scenes showed that polyphony was treated differently in distinct parts of the composition. Polyphony procedures are most represented in the First scenes, then somewhat less in the Fourth scenes, and the least in the Second and Third scenes. The most common is the imitative polyphony, which appears in the First, Second and Fourth scenes. The contrapuntal process of adding melodic lines of new content with already exposed ones, characteristic for First and Third scenes is also evident. The type of duet polyphony is represented, especially in the Second scenes while in the Fourth scenes, the process of joining contrasting themes that were exposed separately prior to joining, is highlighted.

Choreographed scenes Mirska pjenija are an extensive musical achievement of the magnificent spirit, the appearance of which is surprising and also encouraging in the actual time and space.

Acknowledgement: The paper was created as part of the project of the SASA Branch in Niš, Music heritage of South-eastern Serbia, contemporary creativity and taste education (O-10-17).

\section{REFERENCES}

Benjamin, T., (2005), The craft of modal counterpoint, Routledge, New York.

Божанић, 3., (2012), Третман имитације у ренесансној музичкој теорији и пракси, Дани Владе С. Милошевића: Традиција као инспираџија, Соња Маринковић, Санда Додик (ур), Бања Лука, Академија умјетности Универзитета у Бањој Луци, 431-443.

Cherubini, L., (1854), Counterpoint and fugue, Novello, Ewer And Co., London \& New York.

DeVoto, M., (2007), Polyphony. https://www.britannica.com/art/polyphony-music (accessed February 23, 2017).

Кирнарская, Д., (1997),. Классическая музыка для всех: Западноевропейская музыка от григорианского пения до Моциарта, Слово, Москва.

Kolenc, A., (2015),. Leitmotif in a Dynamic Environmen,Georgia, Institute of Technology, accessed February 03. 2019. https://pdfs.semanticscholar.org/a4d2/8b6ba1d67cdac84b8a244803512edad4c4df.pdf.

Конюс Эдуардович, Г., (1930), Курс контрапункта строгого письма в ладах, Музыикальный сектор, Москва.

Merriam-Webster Dictionary, https://www.merriam-webster.com/dictionary/polyphony (accessed May 23, 2019).

Мюллер, Т. \& Григорьев, С., (1977), Учебник полифонии, Издательство Музыка, Москва.

Осипова Дмитриевна, В., (2006), Полифония: учебное пособие: в двух частях, ОмГУ, Омск.

Перичић, В., (1991), Вокални контрапункт за средње музичке школе, Завод за уџбенике и наставна средства, Београд.

Peričić, V., (1987), Instrumentalni i vokalno-instrumentalnikontrapunkt, Univerzitet umetnosti, Beograd.

Плавша, Д., (1967), Увод у музичку уметност, Завод за издавање уџбеника, Београд.

Плавша, Д., (1981), Музика: прошлост, садашњост, личности, облици, Нота, Књажевац.

СкребковаФилатова, М., (1996), Фактура у музици, Виша музичка школа, Ниш.

Симакова Александровна, Н., (2002), Контрапункт строгогостиля и фуга-история, теория, практика, Композитор, Москва.

Веселиновић-Хофман, М., (ур)., (2007).Историја српске музике, Завод за уџбенике, Београд.

Whittall, A., (2019), Leitmotif. accessed February 03, 2019. https://doi.org/10.1093/gmo/9781561592630.article. 16360 . 


\section{VIDOVI POLIFONIJE U OBLIKOVANJU KOREOGRAFSKIH SLIKA MIRSKA PJENIJA SRĐANA JAĆIMOVIĆA}

Polifonija, kao tehnika komponovanja, ima istu funkciju u svakom istorijskom umetničkom periodu - razvoj i obogaćivanje melodijskih linija. Ono po čemu se tretman polifonije razlikuje kroz epohe je drugačiji zvučni utisak stilskog muzičkog perioda u kome je kompozicija nastala. Muzički jezik koreografskih slika Mirska pjenija kompozitora Srđana Jaćimovića je u najvećoj meri muzički jezik naše epohe - jezik postmodernog usmerenja. Delo obiluje impresionističkim prikazivanjem atmosfere kroz muzičko oslikavanje teksta. Detaljna polifona analiza kompozicije ukazuje na upotrebu različitih vrsta polifonije u svakoj koreografskoj slici pojedinačno, koje su u ovom radu sistematski izdvojene i obrazložene.

Ključne reči: polifonija, vidovi polifonije, koreografske slike, Mirska pjenija, Srđan Jaćimović. 